\title{
Silicon recycling through rice residue management does not prevent silicon depletion in paddy rice cultivation
}

\author{
Harold James Hughes $\mathbb{B} \cdot$ Dao Trong Hung • Daniela Sauer
}

Received: 4 October 2019/Accepted: 15 July 2020/Published online: 25 July 2020

(C) The Author(s) 2020

\begin{abstract}
Silicon (Si) is known to help plants mitigate environmental stresses and nutrient deficits. In some regions, the limited plant-available $\mathrm{Si}$ in soils can have detrimental effects on yields. Crop residue recycling is used to maintain the amount of plantavailable $\mathrm{Si}$ in soils. However, the effect of crop residue management practices on $\mathrm{Si}$ availability to plants remains largely understudied. Here, we study the effects of three different rice residue management practices on Si-depleted rice fields in northern Vietnam. These management practices were (1) the direct incorporation of rice residues into soils, (2) burning in the field, and (3) use as fodder for animals, followed by composting of the obtained manure, and subsequent application to the field. We analyzed different $\mathrm{Si}$ reservoirs in soils and the content of plant-Si under these different practices. Our results show correlations between plant $\mathrm{Si}$ content and the different soil $\mathrm{Si}$ reservoirs, in particular with $\mathrm{Si}$ trapped in soil organic material $\left(\mathrm{Si}_{\text {Org }} ; \mathrm{R}^{2}=0.68, \mathrm{n}=18, \mathrm{p}<10^{-4}\right)$. However, we found no significant difference between the three residue management practices with respect to
\end{abstract}

H. J. Hughes $(\bowtie) \cdot$ D. T. Hung · D. Sauer

Department of Physical Geography, Institute of

Geography, Georg-August-Universität Göttingen,

Goldschmidtstraße 5, 37077 Göttingen, Germany

e-mail: hhughes@uni-goettingen.de

D. T. Hung

Soils and Fertilizers Research Institute, Duc Thang,

Bac Tu Liem, Hanoi 1000, Vietnam plant-available $\mathrm{Si}$ in soils and to the content of plant$\mathrm{Si}$. Moreover, our data suggest that strongly Sidepleted rice-cultivation systems proportionally lose $\mathrm{Si}$ through grain harvesting twice as fast as less $\mathrm{Si}$ depleted systems because of the enhanced relative $\mathrm{Si}$ accumulation in grain. This loss cannot be mitigated by the recycling of rice residues, which suggests that the recycling of rice residues has only a limited effect in extremely Si-depleted rice-cultivation systems.

Keywords Rice straw · Phytoliths · Si-depleted soil · $\mathrm{Si}$ extraction $\cdot$ Soil Si pools $\cdot$ Biogenic Si

\section{Introduction}

Rice is the world's most important food crop. More than 750 million tonnes of rice are harvested annually from about 165 million hectares around the world (FAO 2018). With an annual production of ca. 43 million tonnes, Vietnam is one of the largest rice producers and exporters in the world. Ninety percent of the arable land in Vietnam is used for rice cultivation (FAO 2017). From 1992 to 2015, the average amount of chemical nitrogen $(\mathrm{N})$, phosphorus $(\mathrm{P})$, and potassium $(\mathrm{K})$ fertilizers applied in agricultural production in Vietnam doubled. However, while the efficiency of fertilizer usage remains low, its increased application causes considerable losses to the 
national economy and increases eutrophication and greenhouse gas emissions (FAO 2018; MARD 2018; Pham and Nguyen 2014). Rice cultivation produces large amounts of straw, resulting on average in about five tonnes of crop residues per hectare of paddy rice annually (GSO 2017). These residues can be used as a readily available, cost-efficient, and domestically produced organic fertilizer and may be a partial substitute for chemical fertilizers in agriculture (Hoang et al. 2014; Keck et al. 2019; Tran and Hung 2010; Zhao et al. 2009). A more efficient use of crop residues would thus allow Vietnam to reduce the import of chemical fertilizers (MARD 2018). It would also increase farmers' net income by reducing their expenses for chemical fertilizers (Baumann 2014; Bui 2008).

Rice residue management practices may also have an influence on the bio-availability of silicon (Si) in rice fields (Klotzbücher et al. 2016; Savant et al. 1997). Si is generally not considered an essential element for plant growth (Epstein 1994). Yet many studies highlight its strong beneficial effects for a variety of plants, particularly under stress conditions (see Guntzer et al. 2012a for a review). As a consequence, $\mathrm{Si}$ is now broadly recognized as a beneficial element for plants and a quasi-essential nutrient (Coskun et al. 2018; Epstein 1999). Si enhances plant resistance in a large variety of circumstances, including for example nutrient depletion, drought stress, pathogens and pest attacks. There is evidence for multiple combined beneficial effects of Si rather than one single mechanism (Guntzer et al. 2012a; Liang et al. 2015; Rizwan et al. 2015). The functioning of these effects is, however, far from being fully understood and is still subject to debate (Coskun et al. 2018). The quantity of $\mathrm{Si}$ taken up and accumulated by plants varies according to species (Hodson et al. 2005). It is generally accepted that $\mathrm{Si}$ uptake is achieved both by passive uptake ( $\mathrm{Si}$ absorption along with water) and, for Si accumulators, by an active transport process using specific transporters (see Ma and Yamaji 2015 for a review); some authors, however, challenge this approach and have suggested that $\mathrm{Si}$ uptake could be a strictly passive process (Exley 2015; Exley et al. 2020). After its absorption by the plant, part of the Si precipitates in roots (Lux et al. 2020) while the rest is transferred with the xylem to aerial parts of the plants via the transpiration stream (Mitani and Ma 2005) and precipitates mostly in parts of the plants where transpiration takes place, forming amorphous silica structures known as phytoliths (Perry 2003; Piperno 2006). These structures vary greatly in size and shape inside a plant (e.g., Hodson 2016; Meunier et al. 2017; Puppe et al. 2017). Si that has precipitated cannot be re-mobilized by the plants and remains insoluble until it is returned to soil through litter decomposition. When organic matter is decomposed, the Si present in the organic matrix as monomeric silicic acid and small silica polymers ( $\mathrm{Si}_{\text {Org }}$; Currie and Perry 2007; Fraysse et al. 2010) and in small and fragile phytogenic siliceous structures is rapidly released (e.g., Meunier et al. 2017; Puppe et al. 2017), while the release of $\mathrm{Si}$ from more robust phytoliths is comparatively slow (Fraysse et al. 2009, 2010; Puppe et al. 2017). The dissolution rate of phytoliths may also be affected by their physicochemical surface properties, such as their specific surface area and their Al content (Fraysse et al. 2009; Hodson 2016; Puppe and Leue 2018). With time, phytoliths may structurally or chemically alter (e.g., reduction of the reactive surface, development of a protective coating layer) and be stored for longer periods (Alexandre et al. 1997; Bartoli 1981; Sommer et al. 2006). In most soils, Si present in biogenic silica $\left(\mathrm{Si}_{\mathrm{B}}\right)$ accounts for 0.1 to $3 \mathrm{wt} \%$ of the fine earth fraction $(<2 \mathrm{~mm})$, with concentrations generally decreasing with depth (Bartoli 1981; Drees et al. 1989; Georgiadis et al. 2014). Although phytoliths often constitute a major part of $\mathrm{Si}_{\mathrm{B}}$ in soils (Clarke 2003), it is worth noting that other $\mathrm{Si}_{\mathrm{B}}$ pools like testate amoebae and terrestrial diatoms are known to be a very reactive fraction of the $\mathrm{Si}_{\mathrm{B}}$ pool (Puppe et al. 2015; Sommer et al. 2006). Because of its high solubility, $\mathrm{Si}_{\mathrm{B}}$ is assumed to represent an important source of $\mathrm{Si}$ in soil solution (Bartoli 1981; Fraysse et al. 2010). The balance between the different sources of $\mathrm{Si}$ (mineral dissolution $\mathrm{vs}^{\mathrm{Si}_{\mathrm{B}}}$ recycling) absorbed by plants is not yet well established, but there is evidence that, in many ecosystems, soil-plant $\mathrm{Si}$ fluxes involve intense $\mathrm{Si}_{\mathrm{B}}$ recycling and are several times larger than fluxes of Si released from primary minerals via weathering. As a consequence, $\mathrm{Si}$ cycles on average several times through the $\mathrm{Si}_{\mathrm{B}}$ pool before eventually being exported to the hydrological network (Bartoli 1983; Blecker et al. 2006; Clymans et al. 2011; Derry et al. 2005; Struyf et al. 2010). In agricultural environments, regular $\mathrm{Si}_{\mathrm{B}}$ export through crop harvest interrupts this soil-plant recycling loop 
and can thus lead over time to a depletion of the $\mathrm{Si}_{\mathrm{B}}$ pool in soils (Clymans et al. 2011; Struyf et al. 2010; Vandevenne et al. 2012). Several studies have already proved an anthropogenic influence on $\mathrm{Si}_{\mathrm{B}}$ storage and on continental Si fluxes (e.g., Ameijeiras-Mariño et al. 2018; Carey and Fulweiler 2012, 2013; Clymans et al. 2011; Conley and Carey 2015; Fortner et al. 2012; Struyf et al. 2010; Unzué-Belmonte et al. 2017; Vandevenne et al. 2015b; Vandevenne et al. 2015a). Decrease of $\mathrm{Si}_{\mathrm{B}}$ stocks is critical as it may affect yields, in particular for plants grown on highly weathered soils where $\mathrm{Si}$ input from soil mineral dissolution is low.

In rice plants, the average $\mathrm{Si}$ content is usually higher than $40 \mathrm{mg} / \mathrm{g}$ of the dry mass (e.g., Hodson et al. 2005; Savant et al. 1997) and can reach up to $100 \mathrm{mg} / \mathrm{g}$ (Epstein 1994). This high Si content classifies rice as a $\mathrm{Si}$ accumulator and makes the $\mathrm{Si}_{\mathrm{B}}$ export flux through crop harvest even more important. As $\mathrm{Si}$ fertilization is not a common practice in northern Vietnam, this Si export is usually not compensated by the input of Si from fertilizers. Returning crop residues to fields is expected to partially close again the plantsoil Si cycle and reduce the net export of Si. Such Si recycling with crop residues should thus eventually help to maintain appropriate levels of plant-available $\mathrm{Si}$ in cultivated soils.

Each of the three rice residue management techniques studied here may affect the recycling rate of $\mathrm{Si}_{\mathrm{B}}$ in soils and thereby $\mathrm{Si}$ availability to plants. To the best of our knowledge, no study has yet to focus on comparing the effects of different crop residue management practices on Si cycling. Owing to the various beneficial effects of Si for plants mentioned above, the current lack of knowledge about the effect of agricultural practices on the Si cycle is unfortunate. Owing to the gaps in knowledge pointed out above, the objectives of our study were to assess the effects of different rice residue management practices on (i) various soil $\mathrm{Si}$ pools in a Si-depleted system, (ii) Si uptake by rice plants and (iii) rice yields, through the management effects on Si plant-availability. The overall goal of this assessment was to identify management practices that may contribute to a more sustainable rice cultivation in Vietnam.

\section{Material and methods}

Rice residue management techniques

In our study, we tested the effects of three rice residue management practices on Si-depleted paddy rice systems. Each of these crop residue management techniques are commonly found in Vietnam. For all three management practices, grain (including the husk) is exported with the harvest and thus accounts for a net export of Si. Rice residues, to the contrary, are almost entirely recycled back to the fields and should thus only constitute a transient $\mathrm{Si}$ reservoir that is eventually returned to the soil. Unfortunately, a comparison with fields where rice residue is not recycled was not possible as this later practice is not common in the region. The three management practices are:

- Incorporation: Plant residues are spread over the land following a mechanical harvest. They are then incorporated into the soil, thereby burying the $\mathrm{Si}$ contained in straw. Crop residue incorporation into the soil is known to increase soil organic carbon stocks, improve soil structure, and substantially contribute to maintaining appropriate levels of nutrients such as $\mathrm{N}, \mathrm{P}$, and $\mathrm{K}$ in the soil (BijaySingh et al. 2008; Fairhurst et al. 2007; Hoang et al. 2014).

- Burning: In Vietnam, like in many countries, the most common practice is to burn rice residues directly on the field (Tran et al. 2014; Truc et al. 2012). This labor-saving method has the advantage of destroying pests, but it is known to result in a loss of nutrients to the atmosphere, including macronutrients like N, P and K (Fairhurst et al. 2007; Gupta et al. 2004).

- Manure production: Rice residues can be used as fodder for cattle. The obtained manure is then composted and the final product is dispersed back onto the fields of origin.

Study area

The study area is located in the Luong Phong Commune, in the alluvial plain of the Red River, ca. $55 \mathrm{~km}$ north-east of Hanoi, northern Vietnam (Hiep Hoa District, Bac Giang Province; $106^{\circ} 01^{\prime} \mathrm{E}, 21^{\circ}$ $20^{\prime} \mathrm{N}$ ). The climate is humid subtropical with a 
monsoon season. The mean annual temperature is $23.5^{\circ} \mathrm{C}$ and the mean annual rainfall is $1620 \mathrm{~mm}$, of which more than $80 \%$ occurs between May and October. The soils are Plinthic Acrisols according to the World Reference Base for Soil Resources (IUSS Working Group WRB 2015). The texture of the soils is predominantly sandy loam. Acrisols are among the main soils used for agriculture in Vietnam, occupying 1.4 million hectares (12\% of the agricultural land of Vietnam). In northern Vietnam, these soils are concentrated in regions that are known for their intensive agricultural production (Nguyen et al. 2002). The fertility of these soils is, however, generally low (Nguyen et al. 2015). The predominant cropping system is a lowland paddy rice (Oryza sativa L.) system, with two harvests per year. Spring rice is usually planted in February and harvested in late May. Summer rice is planted in late June and harvested in late September. Although some farmers combine rice cultivation with other crops, we focused on plots where only rice is cultivated.

With a median landholding size of 0.63 ha, smallholders are the backbone of Vietnamese agriculture (FAO 2017). Due to this relatively small size of the fields, various management practices can be found within a close proximity. This allows for an easy comparison of the effects of different management practices, whereby other influencing environmental parameters (e.g., climate, irrigation, soil type, geology, topography) can be easily kept similar. For each of the three rice residue management practices we selected three plots $(n=9)$. These plots have an area of ca. 0.03 ha and are all comprised within a radius of ca. $150 \mathrm{~m}$. They thus have an identical climate and similar soils. In addition to rainwater, plots may also receive irrigation water from a nearby dammed lake when rainwater input is insufficient. This source of irrigation water is common to all plots. Soils have a low $\mathrm{pH}$ (average $\mathrm{pH} \mathrm{KCl}=4.5$ ). All plots have been used for rice agriculture for centuries and have been managed with the current practices since 2010. Before 2010, the management technique in use for all fields was the application of manure. NPK chemical fertilizers were applied in similar rates on all plots; these chemical fertilizers contained no Si. We recently presented the results of a study on the effects of crop residue management practices on $\mathrm{N}, \mathrm{P}$ and $\mathrm{K}$ budgets of these plots in a separate article (Trong Hung et al. 2019).
Sampling

Samples of topsoil, crop residues and rice grains were collected at the time of the harvesting of summer rice in September 2015 and September 2017. With $2156 \mathrm{~mm}$ of rainfall, 2015 was particularly rainy, while 2017 was an average year (1624 mm). At each plot, five topsoil samples were taken with a shovel over a depth of $0-20 \mathrm{~cm}$ (corresponding to the root zone layer) within an area of $5 \times 5 \mathrm{~m}$ and were merged in the field. The samples were air-dried and sieved $(<2 \mathrm{~mm})$. Aliquots of these samples were analyzed by Trong Hung et al. (2019) for various parameters, including soil density, $\mathrm{pH}$, total $\mathrm{N}, \mathrm{P}$ and $\mathrm{K}$, and available $\mathrm{P}$ and $\mathrm{K}$. Plant samples were collected from an area of $2 \times 2 \mathrm{~m}$ within the area from which topsoil samples had been taken. Samples of irrigation water were collected at each plot in September 2017, filtered and analyzed for their dissolved Si content using the molybdate-blue colorimetric method. The dissolved $\mathrm{Si}$ content of rainwater was not analyzed, as it is known to be usually negligible (Tegen and Kohfeld 2006).

Si pools in soils

In order to quantify the effects of the different rice residue management practices on the various $\mathrm{Si}$ reservoirs of the paddy soils, we applied a sequential $\mathrm{Si}$ extraction to the soil samples. The extraction followed the procedure developed by Georgiadis et al. (2013, 2015). For each sample, $1 \mathrm{~g}$ of soil material is processed through the whole extraction procedure. The extracts are centrifuged and filtered through paper filters $(1-2 \mu \mathrm{m})$ before analysis. The remaining soil is rinsed several times with deionized water between the single extraction steps. Throughout the successive steps, $\mathrm{Si}$ is extracted from the following reservoirs:

Dissolved and readily mobilized $\mathrm{Si}\left(\mathrm{Si}_{M}\right)$ This fraction mostly corresponds to (1) Si that is dissolved in soil solution and (2) Si that is loosely adsorbed at the surface of the soil minerals and is therefore in quick, dynamic equilibrium with the solution. The soil samples are mixed with $5 \mathrm{ml}$ of calcium chloride solution $(0.01 \mathrm{M})$. The samples are shaken once per hour for one minute over $24 \mathrm{~h}$. After filtration, the $\mathrm{Si}$ content is measured using the molybdate-blue colorimetric method. 
Adsorbed $\mathrm{Si}\left(\mathrm{Si}_{\mathrm{Ads}}\right) \mathrm{Si}$ adsorbed on mineral surfaces is desorbed by adding $10 \mathrm{ml}$ of acetic acid $(0.01 \mathrm{M})$ to the cleaned soil material from step 1 . The samples are shaken once per hour for one minute over $24 \mathrm{~h}$. After filtration, the $\mathrm{Si}$ content is measured using the molybdate-blue colorimetric method.

$S i$ in organic matter $\left(\mathrm{Si}_{\mathrm{Org}}\right)$ When plant materials or soil organic matter are decomposed, $\mathrm{Si}_{\text {Org }}$ turns into $\mathrm{Si}_{\mathrm{M}}$ and thus becomes plant-available. $\mathrm{H}_{2} \mathrm{O}_{2}$ is used to decompose the soil organic matter in order to release the Si present in the organic matrix. The sample is first treated with $20 \mathrm{ml} \mathrm{H}_{2} \mathrm{O}_{2}(17.5 \%)$ at room temperature. Once the reaction subsides, $10 \mathrm{ml}$ of concentrated $\mathrm{H}_{2} \mathrm{O}_{2}(35 \%)$ is added and the samples are put in a shaking hot water bath at $85{ }^{\circ} \mathrm{C}$ until no further reaction is visible. After filtration (PES filters, $0.2 \mu \mathrm{m})$, the extracts are analyzed for Si by use of an atomic emission spectrometer (ICP-AES). Aluminum concentrations are also measured to check for possible contamination from mineral dissolution.

Si occluded in pedogenic oxides and hydroxides $\left(S i_{\text {occ }}\right)$ The plant-availability of $\mathrm{Si}_{\mathrm{Occ}}$ can be coupled to the dissolution and re-precipitation of iron hydroxides during the redox cycles in paddy rice cultivation. Dissolution and re-precipitation of these oxides and hydroxides with changes of redox conditions can scavenge or release Si (Cornelis et al. 2011; Opfergelt et al. 2009; Sommer et al. 2006). Pedogenic oxides and hydroxides are dissolved by adding $50 \mathrm{ml}$ of an ammonium oxalate $(0.2 \mathrm{M})$ and oxalic acid $(0.14 \mathrm{M})$ solution to the samples. After an initial reaction time of $8 \mathrm{~h}$, the samples are exposed to UV light overnight. The centrifuged and filtered extracts are analyzed for Si by use of an ICP-AES.

Amorphous $S i\left(S i_{A m}\right)$ The remaining soil samples are then transferred into $400 \mathrm{ml}$ of a $0.2 \mathrm{M} \mathrm{NaOH}$ solution to extract $\mathrm{Si}$ from amorphous silica following the protocol of Georgiadis et al. (2015). The samples are kept for 7 days and are shaken hourly for one minute. After centrifugation and filtration, Si concentrations in the extracts are measured colorimetrically.

Plant-available $\mathrm{Si}$ : In addition to the different $\mathrm{Si}$ pools measured through the sequential extraction, we also estimate the soil Si fraction readily available to plants. Multiple methods exist to measure this soluble Si pool (Liang et al. 2015; Sauer et al. 2006). One way is to take the sum of $\mathrm{Si}_{\mathrm{M}}$ and $\mathrm{Si}_{\mathrm{Ads}}$ from the sequential extraction $\left(\mathrm{Si}_{\mathrm{M}+\mathrm{Ads}}\right)$, as $\mathrm{Si}_{\mathrm{M}}$ and $\mathrm{Si}_{\text {Ads }}$ are both readily soluble and available to plants (Haynes 2014; Sauer et al. 2006). However, in the literature Na-acetate extraction $\left(\mathrm{Si}_{\text {NaAcet }}\right)$ is more widely used to measure the Si-supplying capacity in soils. In order to allow a comparison between our results and the existing literature we also measured the $\mathrm{Si}$ extracted with the protocol of Imaizumi and Yoshida (1958) as cited in the review of Sauer et al. (2006). Briefly, $1 \mathrm{~g}$ of soil is incubated for $5 \mathrm{~h}$ in $10 \mathrm{ml}$ of $0.18 \mathrm{M}$ sodium acetate adjusted to $\mathrm{pH}=4$ with acetic acid. After centrifugation and filtration, the Si content is measured using the molybdate-blue colorimetric method.

Plant analyses

Plant samples were separated into crop residues (stems and leaves) and rice grain (including husks). They were weighed, air-dried, cut into small pieces, dried at $60-70{ }^{\circ} \mathrm{C}$ to constant weight, and ground to pass through a $0.4 \mathrm{~mm}$ nylon sieve. The Si concentrations of crop residues $\left(\mathrm{Si}_{\text {Straw }}\right)$ and rice grain $\left(\mathrm{Si}_{\text {Grain }}\right)$ were measured by the $1 \% \mathrm{Na}_{2} \mathrm{CO}_{3}$ method (Meunier et al. 2014; Saccone et al. 2007) initially developed for amorphous silica extraction from soil samples. Ca. $20 \mathrm{mg}$ of plant material was weighed into a $50 \mathrm{ml}$ centrifuge tube using a high-precision scale. $40 \mathrm{ml}$ of a $1 \% \mathrm{Na}_{2} \mathrm{CO}_{3}$ solution $(0.094 \mathrm{M})$ was added and the tube was then put into a shaking hot water bath at $85{ }^{\circ} \mathrm{C}$ for minimum $3 \mathrm{~h}$. The tubes were manually shaken hourly to fully mix the samples. After centrifugation ( $5 \mathrm{~min}$ at $3000 \mathrm{rpm}$ ), an aliquot of the solution was neutralized with $\mathrm{HCl}$ and filtered through a paper filter $(1-2 \mu \mathrm{m})$. The sample was then diluted and analyzed with the molybdate-blue colorimetric method. We ensured that no solution contained more than $84 \mu \mathrm{g} / \mathrm{l} \mathrm{Si}$, as recommended by Meunier et al. (2014), as amorphous silica dissolution might be incomplete for samples with higher Si concentrations. All Si extractions in plants were replicated at least once.

\section{Results}

Water

Dissolved Si content in irrigation water sampled at the time of the 2017 harvest is similar in the different fields, ranging from 0.75 to $1.04 \mathrm{mg} / \mathrm{l}$ (average $=0.9 \mathrm{mg} / 1 \pm 0.2 ; 2 \mathrm{SD})$. In comparison, water 


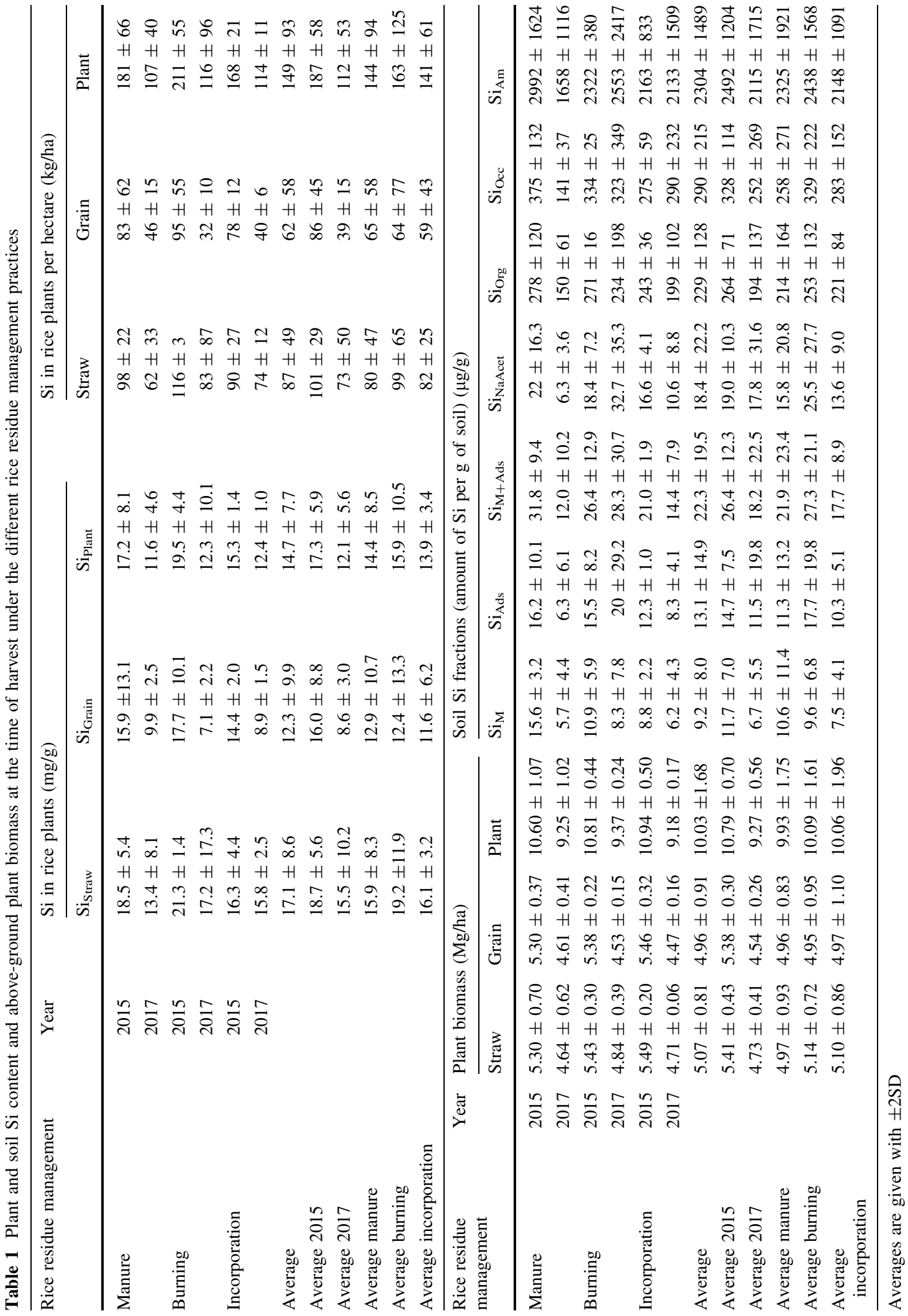


collected at the same time at the dammed lake and used as a complement to rainwater for irrigating the fields had a dissolved Si content of $3.50 \mathrm{mg} / \mathrm{l}$.

\section{Soils}

Si concentrations in the various soil Si reservoirs of the different experimental plots are highly variable. However, our results do not show significant differences between sites with different management practices. The results are summarized in Table $1 . \mathrm{Si}_{\mathrm{Am}}$ is always by far the largest of the different $\mathrm{Si}$ pools considered in our study (on average $2.3 \mathrm{mg} / \mathrm{g}$ and 6.1 $\mathrm{t} / \mathrm{ha}$ for the top $20 \mathrm{~cm}$ layer, using an average soil density of 1.33; Trong Hung et al. 2019). All the considered soil Si reservoirs tend to be correlated with each other to variable degrees. There is a marked difference between samples from 2015 and 2017; under all three management practices, the average $\mathrm{Si}$ content of the different soil reservoirs is systematically either lower or stable in soil samples from 2017 in comparison to samples from 2015. Both estimates of the plant-available $\mathrm{Si}$ (Na-acetate extractable $\mathrm{Si}$ and $\mathrm{Si}_{\mathrm{M}+\text { Ads }}$ from the sequential extraction) show similar results (Fig. 1), but with $\mathrm{Si}_{\mathrm{M}+\text { Ads }}$ being systematically shifted toward higher values by about $5 \mu \mathrm{g} / \mathrm{g}$.

Plants

The average $\mathrm{Si}$ content in the above-ground plant biomass is $15 \mathrm{mg} / \mathrm{g}$ of the dry plant biomass $( \pm 4 \mathrm{mg} / \mathrm{g}$,

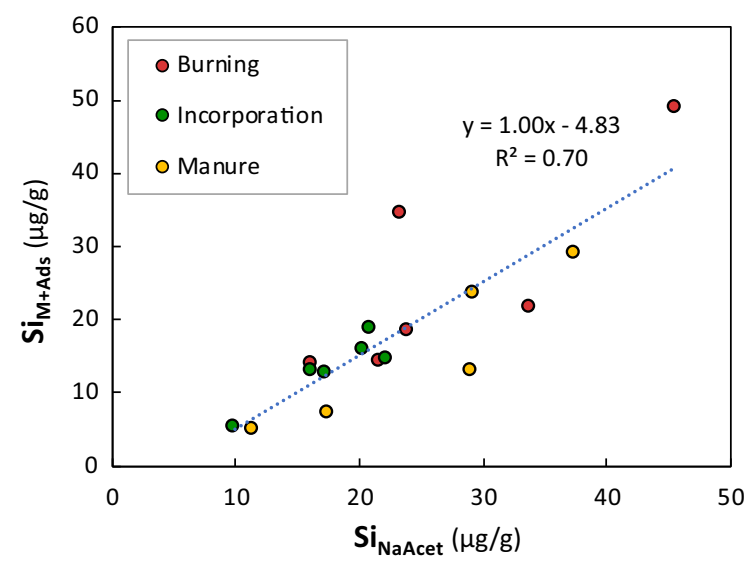

Fig. 1 Relationship between soil Si extraction with Na-acetate $\left(\mathrm{Si}_{\mathrm{NaAcet}}\right)$ and the sum of $\mathrm{Si}_{\mathrm{M}}$ and $\mathrm{Si}_{\mathrm{Ads}}$ from the sequential $\mathrm{Si}$ extraction $\left(\mathrm{Si}_{\mathrm{M}+\mathrm{Ads}}\right)$. Both pools reflect the plant-available $\mathrm{Si}$ in soil
2SD), with generally slightly higher concentrations in straw than in grain $(17 \mathrm{mg} / \mathrm{g}$ and $12 \mathrm{mg} / \mathrm{g}$, respectively). The biomass at the time of harvest is similar for the different plots (average of $10.0 \mathrm{Mg} / \mathrm{ha} \pm 0.8,2 \mathrm{SD}$ ). On average, grain accounts for $49 \%$ of the above-ground plant biomass $( \pm 1 \%, 2 \mathrm{SD})$ and for $41 \%( \pm 8 \%, 2 \mathrm{SD})$ of the $\mathrm{Si}$ present in the above-ground plant biomass. $\mathrm{Si}$ uptake within one growing season ranges from $80 \mathrm{~kg} / \mathrm{ha}$ to $230 \mathrm{~kg} / \mathrm{ha}$. The average $\mathrm{Si}_{\mathrm{Am}}$ stock in the root zone layer $(6.1 \mathrm{t} / \mathrm{ha})$ is thus about 40 times larger than the $\mathrm{Si}$ stored in standing biomass $(0.15 \mathrm{t} / \mathrm{ha})$. Such a ratio between $\mathrm{Si}_{\mathrm{Am}}$ storage in biomass and in soil is similar to values reported for wetlands (Norris and Hackney 1999; Struyf et al. 2005), but lower than the 90:1 ratio reported by Nguyen et al. (2016) for another site in the plain of the Red River. We found no significant difference between the $\mathrm{Si}$ content of the above-ground plant biomass (Si $\left.i_{\text {Plant }}\right)$ under the different rice residue management practices (Table 1). Similar to soil Si reservoirs, average $\mathrm{Si}$ content and Si stock in plants are either lower or stable in plant samples from 2017 in comparison to samples from 2015.

The $\mathrm{Si}$ content in straw $\left(\mathrm{Si}_{\text {Straw }}\right)$ correlates closely with Si content of most of the soil Si reservoirs (Fig. 2), in particular with $\mathrm{Si}_{\mathrm{Ads}}\left(\mathrm{R}^{2}=0.64 ; \mathrm{p}=7 \times 10^{-5}\right)$ and $\mathrm{Si}_{\text {Org }}\left(\mathrm{R}^{2}=0.65 ; \mathrm{p}=3 \times 10^{-5}\right)$. Only between $\mathrm{Si}_{\text {Straw }}$ and $\mathrm{Si}_{\mathrm{M}}$ is no marked correlation found. We also observe a good correlation between $\mathrm{Si}_{\text {Straw }}$ and plantavailable Si estimated both from the sequential extraction $\left(\mathrm{Si}_{\mathrm{M}+\mathrm{Ads}} ; \mathrm{R}^{2}=0.57 ; \mathrm{p}=3 \times 10^{-4}\right)$ and from the Na-acetate extraction $\quad\left(\mathrm{Si}_{\text {NaAcet; }} \quad \mathrm{R}^{2}=0.64\right.$; $\mathrm{p}=2 \times 10^{-4} ; \mathrm{n}=16$, excluding one strong outlier). $\mathrm{Si}_{\text {Straw }}$ also tends to correlate with $\mathrm{Si}_{\text {Occ }}$ and $\mathrm{Si}_{\mathrm{Am}}$ $\left(R^{2}=0.47\right.$ and $R^{2}=0.46$, respectively). In contrast, the $\mathrm{Si}$ content in grain shows only a weak correlation with the Si content in the various soil Si reservoirs. The only noticeable relationship is observed between $\mathrm{Si}_{\text {Grain }}$ and $\mathrm{Si}_{\text {Org }}\left(\mathrm{R}^{2}=0.33\right)$. When considering the $\mathrm{Si}$ content of the whole plant $\left(\mathrm{Si}_{\text {Plant }}\right)$ the most noticeable correlation is with $\mathrm{Si}_{\text {Org }}\left(\mathrm{R}^{2}=0.68, \mathrm{n}=18, \mathrm{p}<10^{-4}\right)$.

\section{Discussion}

Possible effects of the different management practices

Si cycling and $\mathrm{Si}$ availability in rice cultivation have already been the subject of several studies, including 
Fig. 2 Relationships between Si concentrations in rice straw and the different soil Si reservoirs.

$\mathrm{Si}_{\mathrm{M}}=$ mobile $\mathrm{Si}$,

$\mathrm{Si}_{\text {Ads }}=$ adsorbed $\mathrm{Si}$,

$\mathrm{Si}_{\mathrm{M}+\text { Ads }}=$ plant-available $\mathrm{Si}, \mathrm{Si}_{\text {Org }}=\mathrm{Si}$ in soil organic matter, $\mathrm{Si}_{\text {Occ }}=\mathrm{Si}$ occluded in pedogenic oxides, $\mathrm{Si}_{\mathrm{Am}}=\mathrm{Si}$ in amorphous silica
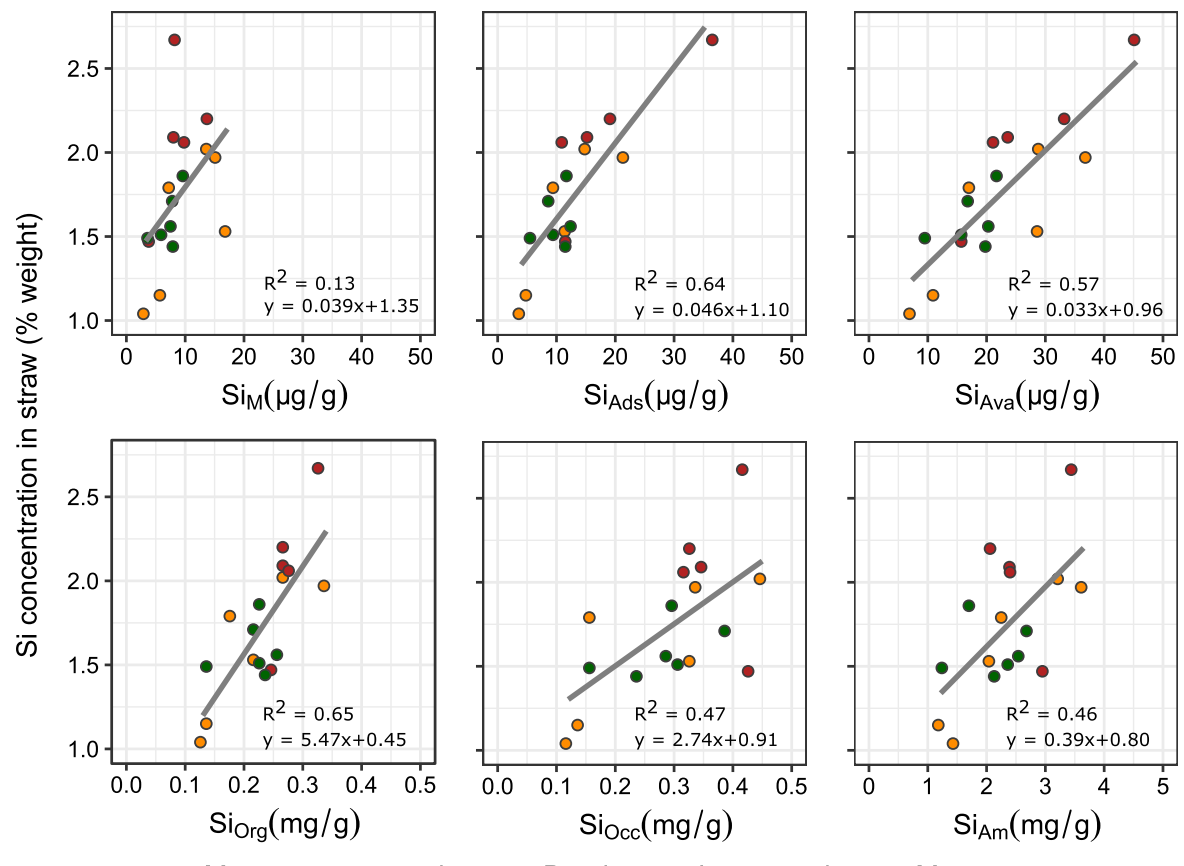

Management practices:

OBurning Oncorporation

OManure some in regions near to our research site (Red River area; e.g., Klotzbücher et al. 2015b, 2016; Marxen et al. 2016). These studies showed a strong $\mathrm{Si}$ limitation in rice cultivation of the Red River area, with a possible effect on yields. They emphasized the importance of recycling crop residues for maintaining a sufficient Si supply to paddy rice in the area, and in regions with low $\mathrm{Si}$ availability in general. In addition, they pointed to a lack of knowledge on the effects of different agricultural practices on $\mathrm{Si}$ availability and called for more studies, in particular on crop residue management. So far, research on the influence of crop residue management on Si bio-availability has focused on comparing the effect of crop residue export against crop residue recycling (e.g., Guntzer et al. 2012b; Klotzbücher et al. 2015a; Marxen et al. 2016; Seyfferth et al. 2013), but no comparison on the impact of different crop residue recycling techniques exists. We know, however, that different treatments and processing of the rice residues may affect in different ways the solubility and the availability of the Si contained in the residues returned to the field:

- Incorporation: When plant residues are incorporated into the soil, the $\mathrm{Si}$ it contains remains embedded in the organic matrix. Like in natural systems, the decomposition of the organic matter will then progressively allow the increased release of $\mathrm{Si}_{\mathrm{B}}$. Studies have shown that the incorporation of plant residues into the soil can markedly increase the $\mathrm{Si}$ concentration in soil solution in comparison to situations where plant residues are exported (Marxen et al. 2016; Savant et al. 1996; Seyfferth et al. 2013).

- Burning: Burning of plant material was shown to enhance the solubility of $\mathrm{Si}_{\mathrm{B}}$ in comparison to unburned plant material (Cabanes et al. 2011; Unzué-Belmonte et al. 2016; Xiao et al. 2014). Nguyen et al. (2014) specifically studied the effect of burning rice straw and concluded that burning at low temperatures (e.g., $400{ }^{\circ} \mathrm{C}$ ) can be an efficient measure for improving $\mathrm{Si}$ availability in the short term. Burning at higher temperature can, however, lead to the transformation of amorphous silica into crystalline, less soluble, forms of silica. Some $\mathrm{Si}$ loss through flying ashes may also occur.

- Manure production: The reactivity of $\mathrm{Si}_{\mathrm{B}}$ was shown to increase after passing through an animal's digestive tract. This is mainly due to degradation of organic matrices, resulting in increased exposure of phytolith surfaces and thus higher dissolution rates (Vandevenne et al. 2013). 
At our study sites, burning and burying practices have been in application since 2010. Given the high recycling rate of Si estimated in similar conditions by Marxen et al. (2016) for buried rice straw (more than half of the plant Si recycled within one month) and by Nguyen et al. (2014) for burned residues, it is reasonable to assume that at the time of the first sampling in $2015 \mathrm{Si}$ fluxes were already near to equilibrium in regards to the respective new management techniques. This assumption is also supported by the large variations in the soil Si content between 2015 and 2017, which shows the highly dynamic nature of this environment.

\section{Sources of bio-available $\mathrm{Si}$}

The strong correlation between plant-available $\mathrm{Si}$ $\left(\mathrm{Si}_{\mathrm{M}+\mathrm{Ads}}\right)$ and the plant $\mathrm{Si}$ content shows the clear link between $\mathrm{Si}$ availability and $\mathrm{Si}$ uptake by plants. However, $\mathrm{Si}_{\mathrm{M}+\mathrm{Ads}}$ amounts on average to less than half of the Si contained in the above-ground biomass at harvest time (Table 1). The $\mathrm{Si}_{\mathrm{M}+\text { Ads }}$ pool must thus be replenished by other $\mathrm{Si}$ sources. Possible $\mathrm{Si}$ sources include $\mathrm{Si}_{\mathrm{Org}}, \mathrm{Si}_{\mathrm{Occ}}, \mathrm{Si}_{\mathrm{Am}}$, lithogenic and pedogenic mineral weathering and irrigation water. Si inputs from irrigation water over a growing season are difficult to quantify, but Si concentration of irrigation water samples was generally low $(<1 \mathrm{mg} / \mathrm{l}$ on average in September 2017). Data on the amount of water from the reservoir lake used for irrigation are lacking, but as the growing season preceding the September harvest corresponds to the rainy season in northern Vietnam it is reasonable to assume that most of the water input is rain water (containing only negligible amounts of Si). Similarly, it is difficult to quantify the Si input from mineral weathering. However, given the high degree of weathering of the soils in the region, input from mineral weathering is expected to be limited in comparison to other soil types, thereby potentially increasing the importance of the different soil Si pools measured in this study as a source of $\mathrm{Si}$ for plants. Among soil $\mathrm{Si}$ sources, $\mathrm{Si}_{\text {Org }}$ and $\mathrm{Si}_{\mathrm{Am}}$ are thought to be important sources of plantavailable $\mathrm{Si}$. In a recent litterbag experiment with $\mathrm{Si}$ poor rice straw, Marxen et al. (2016) measured that $2 / 3$ of the $\mathrm{Si}$ in the straw was released as plant-available $\mathrm{Si}$ within one month. The good correlations observed in our samples between $\mathrm{Si}_{\mathrm{M}+\mathrm{Ads}}$ and both $\mathrm{Si}_{\text {Org }}$ $\left(\mathrm{R}^{2}=0.60 ; \quad \mathrm{p}=10^{-4}\right) \quad$ and $\quad \mathrm{Si}_{\mathrm{Am}} \quad\left(\mathrm{R}^{2}=0.41 ;\right.$ $\mathrm{p}=4 \times 10^{-3}$ ) tend to confirm that the recycling of Si from plants is an important source of plant-available $\mathrm{Si}$. This is also reflected in the strong correlations between these pools and $\mathrm{Si}_{\text {Straw }}$ (Fig. 2). Looking at $\mathrm{Si}_{\mathrm{Am}}$ as a homogeneous $\mathrm{Si}$ reservoir may be misleading though. Given that on average $41 \%$ of the $\mathrm{Si}$ is not returned to the field after harvest, with two annual growing seasons, we can calculate an average residence time of $\mathrm{Si}_{\mathrm{Am}}$ in soil of $34 \mathrm{yrs}$. Such a long average residence time does not reflect the high $\mathrm{Si}_{\mathrm{B}}$ recycling rate reported in the literature for similar environments (Marxen et al. 2016; Nguyen et al. 2014) and for $\mathrm{Si}_{\mathrm{B}}$ recycling in general (e.g., Bartoli 1983; Fraysse et al. 2010). This dichotomy was explained before by a bicompartmental distribution of $\mathrm{Si}_{\mathrm{Am}}$ in soil (Alexandre et al. 1997; Blecker et al. 2006) where part of the $\mathrm{Si}_{\mathrm{B}}$ is recycled quickly while some $\mathrm{Si}_{\mathrm{B}}$ is stored for a longer period in more resistant phytoliths. There is thus a disconnection between the total $\mathrm{Si}_{\mathrm{Am}}$ content in soil and the $\mathrm{Si}_{\mathrm{Am}}$ content effectively available for plants, which makes difficult a precise assessment of the importance of $\mathrm{Si}_{\mathrm{Am}}$ as a source of bio-available $\mathrm{Si}$.

Implications of plant-available Si depletion

The general correlation observed between all soil $\mathrm{Si}$ reservoirs contrasts with results from Klotzbücher et al. (2015a), who observed clear anti-correlations between $\mathrm{Si}_{\mathrm{Am}}$ and plant-available $\mathrm{Si}$ (measured as $\mathrm{Si}_{\text {NaAcet }}$ ), and between $\mathrm{Si}_{\mathrm{Am}}$ and $\mathrm{Si}_{\mathrm{Occ}}$, in paddy soils of the Philippines (Hydragric and Irragric Anthrosols). This may reflect a difference of behavior related to the abundance of $\mathrm{Si}$ in the environment as the rice fields studied in the Philippines presented a high Si availability while the fields studied here are depleted in Si. The average plant Si content of $15 \mathrm{mg} / \mathrm{g}$ found at our research sites is well below values commonly reported for paddy rice systems, which usually exceed $40 \mathrm{mg} / \mathrm{g}$ (e.g., Hodson et al. 2005; Savant et al. 1997; Tsujimoto et al. 2014). Even for other paddy rice plots in the alluvial plain of the Red River Klotzbücher et al. (2015b), and Nguyen et al. (2016) both measured a markedly higher content of average plant $\mathrm{Si}(41 \mathrm{mg} / \mathrm{g}$ and $74 \mathrm{mg} / \mathrm{g}$, respectively). The average rice plant $\mathrm{Si}$ content of $15 \mathrm{mg} / \mathrm{g}$ reported here is also well below the threshold of $50 \mathrm{mg} / \mathrm{g}$ proposed by Dobermann and Fairhurst (2000) below which Si deficiency affects rice plants and yields. These findings classify the plants in 
our study as strongly Si-depleted. These fields are thus ideal for observing the effects of different management practices on Si plant-availability as any minor change in Si input to these Si-depleted systems should have a proportionally larger effect on the bioavailable Si content of the soil than in systems where plantavailable $\mathrm{Si}$ is abundant.

Since Si may be actively taken up by rice plants, the $\mathrm{Si}$ content of the plants and the bioavailable $\mathrm{Si}$ in the soil need not be necessarily systematically correlated. However, in a previous study on soil-plant Si cycling in rice fields, Klotzbücher et al. (2016) found a positive relationship between $\mathrm{Si}_{\text {Straw }}$ and $\mathrm{Si}_{\mathrm{NaAcet}}$. This correlation was limited to $\mathrm{Si}_{\text {Straw }}$ concentrations below ca. $80-100 \mathrm{mg} / \mathrm{g}$. Above this threshold, rice plants probably reached a maximum uptake capacity and
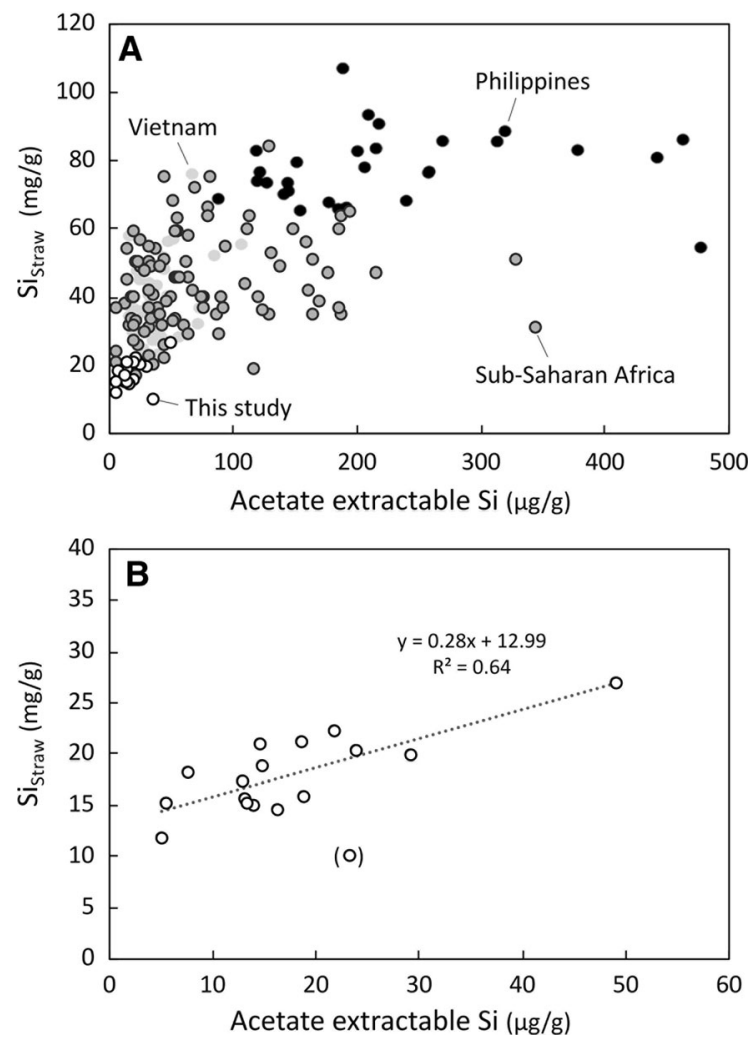

Fig. 3 a Relationship between the Si content in rice straw and plant-available Si in soil measured by acetate extraction. Data from our study clearly lie at the lower end of the entire dataset for both parameters. Sub-Saharan data are from Tsujimoto et al. (2014), Philippine data and additional Vietnamese data are from Klotzbücher et al. (2016). b Close-up of the data from this study showing the strong relationship between the two parameters. One outlier was removed from the trendline and the determination coefficient calculation additional $\mathrm{Si}_{\mathrm{NaAcet}}$ did not lead to a further increase of plant Si content (Fig. 3). A similar threshold effect was also observed in rice agriculture from Louisiana, USA, by Paye (2016). As the Si content of our plant samples is always below $30 \mathrm{mg} / \mathrm{g}$, it falls well within the range for which Klotzbücher et al. (2016) found the correlation between plant Si content and plantavailable $\mathrm{Si}$ in soils. In agreement with this later study, the clear correlation shown in our data between $\mathrm{Si}_{\text {Straw }}$ and both $\mathrm{Si}_{\mathrm{M}+\mathrm{Ads}}$ and $\mathrm{Si}_{\mathrm{NaAcet}}$ suggests a direct link between $\mathrm{Si}_{\text {Straw }}$ and soluble $\mathrm{Si}$ in soil. We thus conclude that Si uptake at our study sites was limited by the Si availability in the soil.

Causes for the absence of differences between management practices

Given the low Si plant-availability in our study area, we had expected that small differences in $\mathrm{Si}$ input would lead to more easily measurable effects on the content of plant $\mathrm{Si}$ than in systems with higher $\mathrm{Si}$ plant-availability. However, our data do not show any significant differences in plant $\mathrm{Si}$ content between the different management practices (Table 1). Caution must be exercised though in the interpretation of these results due to the limited size of the dataset. A first possible explanation to the absence of significant differences in Si content of rice plants grown under the three different management practices could simply be that the recycling of $\mathrm{Si}_{\mathrm{B}}$ is particularly efficient under the present humid-subtropical climate. All three management practices involve recycling of the $\mathrm{Si}$ in crop residues. Thus, if for all three management practices the $\mathrm{Si}_{\mathrm{B}}$ is recycled at a similar rate, this might result in a similar plant-availability of $\mathrm{Si}$. Another possible explanation for the absence of clear differences between the three management practices is the high $\mathrm{Si}$ export rate through grain harvesting. As the $\mathrm{Si}$ contained in the rice grains is exported from the system and is thus not recycled on the field, this regular export (twice a year) leads to a considerable systematic loss of $\mathrm{Si}_{\mathrm{B}}$ from the system. Possible effects of different $\mathrm{Si}$ recycling rates by the three management techniques might thus be obscured by $\mathrm{Si}$ export with grain. This $\mathrm{Si}$ loss during harvest is, moreover, enhanced at our study sites as $\mathrm{Si}_{\text {Grain }}$ comprises a particularly large proportion of $\mathrm{Si}_{\text {Plant }}$ compared to other studies. On average, at harvest time grain accounted for $49 \%$ of the total aerial plant 


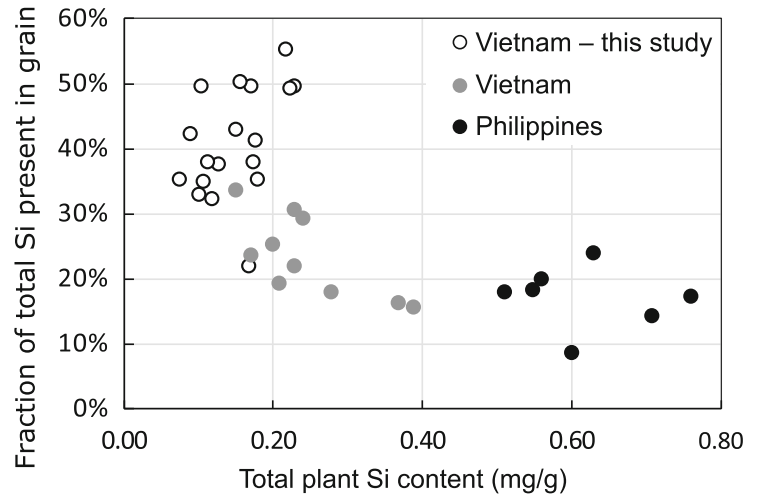

Fig. 4 Proportion of $\mathrm{Si}$ in rice grains relative to the total plant $\mathrm{Si}$ content. Additional data are from Klotzbücher et al. (2016)

biomass $( \pm 1 \%, 2 \mathrm{SD})$ and for $41 \%( \pm 8 \%, 2 \mathrm{SD})$ of the $\mathrm{Si}$ present in the above-ground plant biomass (Fig. 4). This is relatively high compared to data from other studies. For example, Klotzbücher et al. (2016) reported a Si content in grain accounting for $20 \%$ of the $\mathrm{Si}$ in the above-ground plant (23\% for Vietnamese rice and $17 \%$ for Philippine rice). This finding also raises the question whether the high proportion of $\mathrm{Si}_{\text {Grain }}$ in $\mathrm{Si}_{\text {Plant }}$ is a consequence of the low content of plant-available $\mathrm{Si}$ in the soils. Unfortunately, few studies have measured both $\mathrm{Si}_{\mathrm{Grain}}$ and $\mathrm{Si}_{\text {Plant }}$, but the limited data shows that there might be a negative correlation between these two parameters (Fig. 4). If this is the case, it may trigger a snowball effect in which a low content of plant-available Si in soils leads to a higher fraction of $\mathrm{Si}_{\text {Plant }}$ being stored in grain, thus eventually resulting in a proportionally greater $\mathrm{Si}$ export during the harvest of the rice grains. Such a snowball effect would have serious implications, as it would mean that the more $\mathrm{Si}$-depleted a soil already is, the higher is the proportion of plant-available Si lost from the system via grain export. This hypothesis can easily be tested in future studies by systematically measuring the Si content in grain along with that in bulk plants or in straw.

\section{Conclusions}

The absence of any difference in the plant-availability of $\mathrm{Si}$ between the three crop residue management practices suggests that it is therefore not necessary to take Si recycling into account when deciding which of these practices to adopt. This simplifies the decision- making process and allows more emphasis to be put on the recycling of other nutrients. Our results also highlight the importance of $\mathrm{Si}$ fertilization in $\mathrm{Si}$ depleted systems, not only in the short term to improve yield, but also on the longer term to avoid an increasingly rapid depletion of plant-available $\mathrm{Si}$ in soils as $\mathrm{Si}$ is exported with grain. It also emphasizes the need for a better constraint on the impact of $\mathrm{Si}$ input from recycling (or fertilization) on the other $\mathrm{Si}$ fluxes of the system, since it is, for example, not clear to what extent the recycling of $\mathrm{Si}$ influences mineral dissolution. In future studies, it would thus be helpful to analyze plots where $\mathrm{Si}$ input from recycling and/or fertilization is equal or higher than $\mathrm{Si}$ output during harvest. This will allow the finding of the tipping point where the plant-soil system reaches a $\mathrm{Si}$ equilibrium and beyond which Si starts accumulating in soils. Such information will help quantify the need for Si fertilization. An additional comparison with rice plots where rice residues are not returned to the field at all, and where all plant $\mathrm{Si}$ is thus exported, would also be necessary in order to better assess the exact benefit of returning the Si contained in rice residues to the fields.

Acknowledgements Open Access funding provided by Projekt DEAL. We kindly thank the Ministry of Education and Training in Vietnam for financing this research as part of the PhD study of Mr. Dao Trong Hung (Grant No. 800/Q-DBGDD). We thank the staff at the Soils and Fertilizers Research Institute, Duc Thang, Bac Tu Liem, Hanoi, Vietnam for supporting our fieldwork.

Open Access This article is licensed under a Creative Commons Attribution 4.0 International License, which permits use, sharing, adaptation, distribution and reproduction in any medium or format, as long as you give appropriate credit to the original author(s) and the source, provide a link to the Creative Commons licence, and indicate if changes were made. The images or other third party material in this article are included in the article's Creative Commons licence, unless indicated otherwise in a credit line to the material. If material is not included in the article's Creative Commons licence and your intended use is not permitted by statutory regulation or exceeds the permitted use, you will need to obtain permission directly from the copyright holder. To view a copy of this licence, visit http://creativecommons.org/licenses/by/4.0/.

\section{References}

Alexandre A, Meunier J-D, Colin F, Koud J-M (1997) Plant impact on the biogeochmical cycle of silicon and related weathering processes. Earth Planet Sci Lett 61(3):677-682 
Ameijeiras-Mariño Y, Opfergelt S, Derry LA, Robinet J, Govers G, Minella JPG, Delmelle P (2018) Ge/Si ratios point to increased contribution from deeper mineral weathering to streams after forest conversion to cropland. Appl Geochem 96:24-34. https://doi.org/10.1016/j.apgeochem.2018.06. 002

Bartoli F (1981) Le cycle biogeochimique du silicium sur roche acide: application à deux écosystèmes forestiers tempérésrés (Vosges). Doctoral thesis, Université de Nancy

Bartoli F (1983) The biogeochemical cycle of silicon in two temperate forest ecosystems. Ecological Bulletins 35:469-476

Baumann L (2014) Insights into Vulnerability of Smallholder Farming Systems in the Upland Region of North Vietnam. Master thesis, Swiss Federal Institute of Technology

Bijay-Singh YH, Shan S-B, Yadvinder-Singh RJB (2008) Chapter 3 crop residue management for lowland rice-based cropping systems in Asia. In: Sparks DL (ed) Advances in agronomy. Academic Press, London, pp 117-199

Blecker SW, McCulley RL, Chadwick OA, Kelly EF (2006) Biologic cycling of silica across a grassland bioclimosequence. Global Biogeochem Cycles 20(3):3023

Bui HH (2008) Assessing the present use of chemical fertilizers and promoting methods to improve the use of fertilizers for crop production in Vietnam. Soils and Fertilizers Research Institute, Hanoi

Cabanes D, Weiner S, Shahack-Gross R (2011) Stability of phytoliths in the archaeological record: a dissolution study of modern and fossil phytoliths. J Archaeol Sci 38(9):2480-2490. https://doi.org/10.1016/j.jas.2011.05. 020

Carey JC, Fulweiler RW (2012) Human activities directly alter watershed dissolved silica fluxes. Biogeochemistry 111(1-3):125-138. https://doi.org/10.1007/s10533-0119671-2

Carey JC, Fulweiler RW (2013) Watershed land use alters riverine silica cycling. Biogeochemistry 113(1-3):525-544. https://doi.org/10.1007/s10533-0129784-2

Clarke J (2003) The occurrence and significance of biogenic opal in the regolith. Earth Sci Rev 60(3):175-194. https:// doi.org/10.1016/S0012-8252(02)00092-2

Clymans W, Struyf E, Govers G, Vandevenne F, Conley DJ (2011) Anthropogenic impact on amorphous silica pools in temperate soils. Biogeosciences 8(8):2281-2293. https:// doi.org/10.5194/bg-8-2281-2011

Conley DJ, Carey JC (2015) Biogeochemistry: Silica cycling over geologic time. Nat Geosci 8(6):431-432

Cornelis J-T, Titeux H, Ranger J, Delvaux B (2011) Identification and distribution of the readily soluble silicon pool in a temperate forest soil below three distinct tree species. Plant Soil 342(1):369-378. https://doi.org/10.1007/ s11104-010-0702-x

Coskun D, Deshmukh R, Sonah H, Menzies JG, Reynolds O, Ma JF, Kronzucker HJ, Bélanger RR (2018) The controversies of siliconltextquotesingles role in plant biology. New Phytol 221(1):67-85. https://doi.org/10.1111/nph.15343

Currie HA, Perry CC (2007) Silica in plants: biological, biochemical and chemical studies. Ann Bot 100(7):1383-1389. https://doi.org/10.1093/aob/mcm247
Derry LA, Kurtz AC, Ziegler K, Chadwick OA (2005) Biological control of terrestrial silica cycling and export fluxes to watersheds. Nature 433:728-731

Dobermann A, Fairhurst T (2000) Rice nutrient disorders \& nutrient management. International Rice Reaserch Institute; IRRI, Los Banos

Drees LR, Wilding LP, Smeck NE, Senkayi AL (1989) Chapter 19 Silica in soils quartz and disordered silica polymorphs soil science: minerals in soil environments. In: Dixon JB (ed) Soil Sci Soc Am., Madison, WI, United States, pp 913-975

Epstein E (1994) The anomaly of silicon in plant biology. Proc Natl Acad Sci 91(1):11-17

Epstein E (1999) Silicon. Annu Rev Plant Physiol Plant Mol Biol 50(1):641-664. https://doi.org/10.1146/annurev. arplant.50.1.641

Exley C (2015) A possible mechanism of biological silicification in plants. Front Plant Sci 6:853. https://doi.org/10. 3389/fpls.2015.00853

Exley C, Guerriero G, Lopez X (2020) How is silicic acid transported in plants? Silicon 665(10):432. https://doi.org/ 10.1007/s12633-019-00360-w

Fairhurst T, Witt C, Buresh R, Dobermann A (2007) Rice: a practical guide to nutrient management, 2nd edn. International Rice Research Institute, Los Baños, Philippines

FAO (2017) Smallholders Data Portrait: Family Farming Knowledge Platform. Viet Nam (i8358EN/1/02.18), Food and Agriculture Organization. https://www.fao.org/familyfarming/data-sources/\%2520dataportrait/farm-size/en/. Accessed 26 Sep 2019

FAO (2018) FAOSTAT Database, Food and Agriculture Organization. https://www.fao.org/faostat/en/\#data/EF. Accessed 26 Sept 2019

Fortner SK, Lyons WB, Carey AE, Shipitalo MJ, Welch SA, Welch KA (2012) Silicate weathering and CO2 consumption within agricultural landscapes, the Ohio-Tennessee River Basin, USA. Biogeosciences 9(3):941-955. https://doi.org/10.5194/bg-9-941-2012

Fraysse F, Pokrovsky OS, Schott J, Meunier J-D (2009) Surface chemistry and reactivity of plant phytoliths in aqueous solutions. Chem Geol 258:197-206

Fraysse F, Pokrovsky OS, Meunier J-D (2010) Experimental study of terrestrial plant litter interaction with aqueous solutions. Geochim Cosmochim Acta 74(1):70-84. https:// doi.org/10.1016/j.gca.2009.09.002

Georgiadis A, Sauer D, Herrmann L, Breuer J, Zarei M, Stahr K (2013) Development of a method for sequential Si extraction from soils. Geoderma 209-210:251-261. https://doi.org/10.1016/j.geoderma.2013.06.023

Georgiadis A, Sauer D, Herrmann L, Breuer J, Zarei M, Stahr K (2014) Testing a new method for sequential silicon extraction on soils of a temperate-humid climate. Soil Res 52(7):645-657. https://doi.org/10.1071/SR14016

Georgiadis A, Sauer D, Breuer J, Herrmann L, Rennert T, Stahr K (2015) Optimising the extraction of amorphous silica by $\mathrm{NaOH}$ from soils of temperate-humid climate. Soil Res 53(4):392. https://doi.org/10.1071/sr14171

GSO (2017) Statistical summary book of Vietnam. General Statistics Office of Vietnam, Hanoi, Vietnam

Guntzer F, Keller C, Meunier J-D (2012) Benefits of plant silicon for crops: a review. Agron Sustain Dev 
32(1):201-213. https://doi.org/10.1007/s13593-011-00398

Guntzer F, Keller C, Poulton PR, McGrath SP, Meunier J-D (2012) Long-term removal of wheat straw decreases soil amorphous silica at Broadbalk Rothamsted. Plant Soil 352(1-2):173-184. https://doi.org/10.1007/s11104-0110987-4

Gupta PK, Sahai S, Singh N, Dixit CK, Singh DP, Sharma C, Tiwari MK, Gupta RK, Garg SC (2004) Residue burning in rice-wheat cropping system: causes and implications. Curr Sci 87(12): 1713-1717

Haynes RJ (2014) A contemporary overview of silicon availability in agricultural soils. J Plant Nutr Soil Sci 177(6):831-844. https://doi.org/10.1002/jpln.201400202

Hoang NT, Tran TT, Dao TH, Nguyen NM, Pham TN, Nguyen TN, Nguyen HT, Vu DQ, Ho CT (2014) Effect of agricultural residues incorporation into soils on increasing crops yield, reducing mineral fertilizers applied and improving soil properties: the results of soils and fertilizers research. Agricultural Publishing, Hanoi, Vietnam

Hodson MJ (2016) The development of phytoliths in plants and its influence on their chemistry and isotopic composition. Implications for palaeoecology and archaeology. J Archaeol Sci 68:62-69. https://doi.org/10.1016/j.jas.2015.09. 002

Hodson MJ, White PJ, Mead A, Broadley MR (2005) Phylogenetic variation in the silicon composition of plants. Ann Bot 96(6):1027-1046. https://doi.org/10.1093/aob/mci255

Imaizumi K, Yoshidai S (1958) Edaphological studies on the silicon supplying power of paddy soils. Bull Natl Inst Agric Sci Tokyo B8:261-304

IUSS Working Group WRB (2015) World reference base for soil resources 2014, update 2015: International soil classification system for naming soils and creating legends for soil maps. FAO, Rome

Keck M, Trong Hung D, Hung DT (2019) Burn or bury? A comparative cost-benefit analysis of crop residue management practices among smallholder rice farmers in northern Vietnam. Sustain Sci 14(2):375-389. https://doi. org/10.1007/s11625-018-0592-Z

Klotzbücher T, Leuther F, Marxen A, Vetterlein D, Horgan FG, Jahn R (2015) Forms and fluxes of potential plant-available silicon in irrigated lowland rice production (Laguna, the Philippines). Plant Soil 393(1-2):177-191. https://doi.org/ 10.1007/s11104-015-2480-y

Klotzbücher T, Marxen A, Vetterlein D, Schneiker J, Türke M, van Sinh N, Hung Manh N, van Chien H, Marquez L, Villareal S, Bustamante JV, Jahn R (2015) Plant-available silicon in paddy soils as a key factor for sustainable rice production in Southeast Asia. Basic Appl Ecol 16(8):665-673. https://doi.org/10.1016/j.baae.2014.08. 002

Klotzbücher T, Marxen A, Jahn R, Vetterlein D (2016) Silicon cycle in rice paddy fields: insights provided by relations between silicon forms in topsoils and plant silicon uptake. Nutr Cycl Agroecosyst 105(2):157-168. https://doi.org/10. 1007/s10705-016-9782-1

Liang Y, Nikolic M, Bélanger R, Gong H, Song A (2015) Silicon in agriculture: from theory to practice. Springer, New York
Lux A, Lukačová Z, Vaculík M, Švubová R, Kohanová J, Soukup M, Martinka M, Bokor B (2020) Silicification of root tissues. Plants (Basel, Switzerland). https://doi.org/10. 3390/plants9010111

Ma JF, Yamaji N (2015) A cooperative system of silicon transport in plants. Trends Plant Sci 20(7):435-442. https:// doi.org/10.1016/j.tplants.2015.04.007

MARD (2018) Annual Report 2017 of Fertilizers Sector. Ministry of Agriculture \& Rural Development, Hanoi, Vietnam

Marxen A, Klotzbücher T, Jahn R, Kaiser K, Nguyen VS, Schmidt A, Schädler M, Vetterlein D (2016) Interaction between silicon cycling and straw decomposition in a silicon deficient rice production system. Plant Soil 398(1):153-163. https://doi.org/10.1007/s11104-0152645-8

Meunier JD, Keller C, Guntzer F, Riotte J, Braun JJ, Anupama K (2014) Assessment of the $1 \% \mathrm{Na} 2 \mathrm{CO} 3$ technique to quantify the phytolith pool. Geoderma 216:30-35. https:// doi.org/10.1016/j.geoderma.2013.10.014

Meunier JD, Barboni D, Anwar-Ul-Haq M, Levard C, Chaurand P, Vidal V, Grauby O, Huc R, Laffont-Schwob I, Rabier J, Keller C (2017) Effect of phytoliths for mitigating water stress in durum wheat. New Phytol 215(1):229-239. https://doi.org/10.1111/nph.14554

Mitani N, Ma JF (2005) Uptake system of silicon in different plant species. J Exp Bot 56(414):1255-1261. https://doi. org/10.1093/jxb/eri121

Nguyen VB, Bui DD, Ho QD, Bui HH, Dang TL, Thai P, Nguyen VT (2002) The basic information of main soil units of Vietnam. National Institute for Soils and Fertilizer

Nguyen MN, Dultz S, Guggenberger G (2014) Effects of pretreatment and solution chemistry on solubility of rice-straw phytoliths. J Plant Nutr Soil Sci 177(3):349-359. https:// doi.org/10.1002/jpln.201300056

Nguyen TL, Truong XC, Nguyen VH, Dinh VS (2015) Survey and Evaluate Fertility Soils Map for Intensive Crop Restructuring and Sustainable Agricultural Land Resources Management in Viet Yen District, Yen Dung District, Luc Nam District, Yen District, Son Dong District and Bac Giang city, Bac Giang Province. Soils and Fertilizers Research Institute: Hanoi, Vietnam

Nguyen MN, Dultz S, Picardal F, Bui ATK, Pham QV, Dam TTN, Nguyen CX, Nguyen NT, Bui HT (2016) Simulation of silicon leaching from flooded rice paddy soils in the Red River Delta, Vietnam. Chemosphere 145:450-456. https:// doi.org/10.1016/j.chemosphere.2015.11.104

Norris AR, Hackney CT (1999) Silica content of a Mesohaline Tidal Marsh in North Carolina. Estuar Coast Shelf Sci 49(4):597-605

Opfergelt S, de Bournonville G, Cardinal D, André L, Delstanche S, Delvaux B (2009) Impact of soil weathering degree on silicon isotopic fractionation during adsorption onto iron oxides in basaltic ash soils, Cameroon. Geochim Cosmochim Acta 73:7226-7240

Paye WS (2016) Silicon fertilization in rice: Establishment of critical silicon level and its impact on availability of nutrients in soils of Louisiana. Master thesis, Louisiana State University

Perry CC (2003) Silicification: the processes by which organisms capture and mineralize silica. In: Dove PM, Yoreo J de, Weiner S (eds) Biomineralization, pp 291-328 
Pham QH, Nguyen VB (eds) (2014) Fertilizer and Mitigation of greenhouse gas emission: national workshop on measures for improving fertilizer use efficiency in Vietnam (March 28, 2014)

Piperno DR (2006) Phytoliths: a comprehensive guide for archaeologists and paleoecologists. AltaMira Press, Lanham Md., Oxford

Puppe D, Leue M (2018) Physicochemical surface properties of different biogenic silicon structures: results from spectroscopic and microscopic analyses of protistic and phytogenic silica. Geoderma 330:212-220. https://doi.org/10. 1016/j.geoderma.2018.06.001

Puppe D, Ehrmann O, Kaczorek D, Wanner M, Sommer M (2015) The protozoic Si pool in temperate forest ecosystems-Quantification, abiotic controls and interactions with earthworms. Geoderma 243-244:196-204. https:// doi.org/10.1016/j.geoderma.2014.12.018

Puppe D, Höhn A, Kaczorek D, Wanner M, Wehrhan M, Sommer M (2017) How big is the influence of biogenic silicon pools on short-term changes in water-soluble silicon in soils? Implications from a study of a 10-year-old soilplant system. Biogeosciences 14(22):5239-5252. https:// doi.org/10.5194/bg-14-5239-2017

Rizwan M, Ali S, Ibrahim M, Farid M, Adrees M, Bharwana SA, Zia-Ur-Rehman M, Qayyum MF, Abbas F (2015) Mechanisms of silicon-mediated alleviation of drought and salt stress in plants: a review. Environ Sci Pollut Res 22(20):15416-15431. https://doi.org/10.1007/s11356-015$5305-\mathrm{x}$

Saccone L, Conley DJ, Koning E, Sauer D, Sommer M, Kaczorek D, Blecker SW, Kelly EF (2007) Assessing the extraction and quantification of amorphous silica in soils of forest and grassland ecosystems. Eur J Soil Sci 58(6):1446-1459

Sauer D, Saccone L, Conley DJ, Herrmann L, Sommer M (2006) Review of methodologies for extracting plant-available and amorphous Si from soils and aquatic sediments. Biogeochemistry 80(1):89-108

Savant NK, Snyder GH, Datnoff LE (1996) Silicon management and sustainable rice production. In: Donald L, Sparks (ed) Academic Press, pp 151-199

Savant NK, Datnoff LE, Snyder GH (1997) Depletion of plantavailable silicon in soils: a possible cause of declining rice yields. Commun Soil Sci Plant Anal 28(13-14):1245-1252. https://doi.org/10.1080/ 00103629709369870

Seyfferth AL, Kocar BD, Lee JA, Fendorf S (2013) Seasonal dynamics of dissolved silicon in a rice cropping system after straw incorporation. Geochim Cosmochim Acta 123:120-133. https://doi.org/10.1016/j.gca.2013.09.015

Sommer M, Kaczorek D, Kuzyakov Y, Breuer J (2006) Silicon pools and fluxes in soils and landscapes - a review. J Plant Nutr Soil Sci 169:310-329

Struyf E, van Damme S, Gribsholt B, Middelburg JJ, Meire P (2005) Biogenic silica in tidal freshwater marsh sediments and vegetation (Schelde estuary, Belgium). Mar Ecol Prog Ser 303:51-60

Struyf E, Smis A, van Damme S, Garnier J, Govers G, van Wesemael B, Conley DJ, Batelaan O, Frot E, Clymans W et al (2010) Historical land use change has lowered terrestrial silica mobilization. Nat Commun 1(8):129
Tegen I, Kohfeld KE (2006) 7: Atmospheric transport of silicon. In: Ittekkot V (ed) The silicon cycle: human perturbations and impacts on aquatic systems. Island Press, Washington, D.C., p 81

Tran TT, Hung TD (2010) Effect of crop by-product on yield and possibility of reducing potassium application rate for crops under rice-based cropping systems on marine sandy soils and grey-degraded soils. Vietnam Soil Sci J 33:89-95

Tran SN, Nguyen THN, Nguyen HC, Nguyen VCN, Le HV, Kield I (2014) To quantify the seasonal rice straw and its use in different provinces in the Vietnamese Mekong Delta. J Sci Can Tho Univ 32:87-93

Trong Hung D, Hughes HJ, Keck M, Sauer D (2019) Riceresidue management practices of smallholder farms in vietnam and their effects on nutrient fluxes in the soil-plant system. Sustainability 11(6):1641. https://doi.org/10.3390/ su11061641

Truc NTT, Sumalde ZM, Espaldon MVO, Pacardo EP, Rapera CL, Palis FG (2012) Farmers' awareness and factors affecting adoption of rapid composting in Mekong Delta, Vietnam and Central Luzon, Philippines. J Environ Sci Manag 15(2):59-73

Tsujimoto Y, Muranaka S, Saito K, Asai H (2014) Limited Sinutrient status of rice plants in relation to plant-available $\mathrm{Si}$ of soils, nitrogen fertilizer application, and rice-growing environments across Sub-Saharan Africa. Field Crops Res 155:1-9. https://doi.org/10.1016/j.fcr.2013.10.003

Unzué-Belmonte D, Struyf E, Clymans W, Tischer A, Potthast K, Bremer M, Meire P, Schaller J (2016) Fire enhances solubility of biogenic silica. Sci Total Environ 572(Supplement C):1289-1296. https://doi.org/10.1016/j. scitotenv.2015.12.085

Unzué-Belmonte D, Ameijeiras-Mariño Y, Opfergelt S, Cornelis J-T, Barão L, Minella J, Meire P, Struyf E (2017) Land use change affects biogenic silica pool distribution in a subtropical soil toposequence. Solid Earth 8(4):737-750. https://doi.org/10.5194/se-8-737-2017

Vandevenne F, Struyf E, Clymans W, Meire P (2012) Agricultural silica harvest: have humans created a new loop in the global silica cycle? Front Ecol Environ 10(5):243-248. https://doi.org/10.1890/110046

Vandevenne FI, Barão LA, Schoelynck J, Smis A, Ryken N, Van Damme S, Meire P, Struyf E (2013) Grazers: biocatalysts of terrestrial silica cycling. Proc R Soc B Biol Sci 280(1772):20132083. https://doi.org/10.1098/rspb.2013. 2083

Vandevenne FI, Barão L, Ronchi B, Govers G, Meire P, Kelly EF, Struyf E (2015) Silicon pools in human impacted soils of temperate zones. Global Biogeochem Cycles 29(9):1439-1450. https://doi.org/10.1002/2014GB005049

Vandevenne FI, Delvaux C, Hughes HJ, André L, Ronchi B, Clymans W, Barão L, Govers G, Meire P, Struyf E (2015) Landscape cultivation alters $\delta 30 \mathrm{Si}$ signature in terrestrial ecosystems. Sci Rep 5:7732. https://doi.org/10.1038/ srep07732

Xiao X, Chen B, Zhu L (2014) Transformation, morphology, and dissolution of silicon and carbon in rice straw-derived biochars under different pyrolytic temperatures. Environ Sci Technol 48(6):3411-3419. https://doi.org/10.1021/ es405676h 
Zhao Y, Wang P, Li J, Chen Y, Ying X, Liu S (2009) The effects of two organic manures on soil properties and crop yields on a temperate calcareous soil under a wheat-maize cropping system. Eur J Agron 31(1):36-42. https://doi.org/ 10.1016/j.eja.2009.03.001
Publisher's Note Springer Nature remains neutral with regard to jurisdictional claims in published maps and institutional affiliations. 